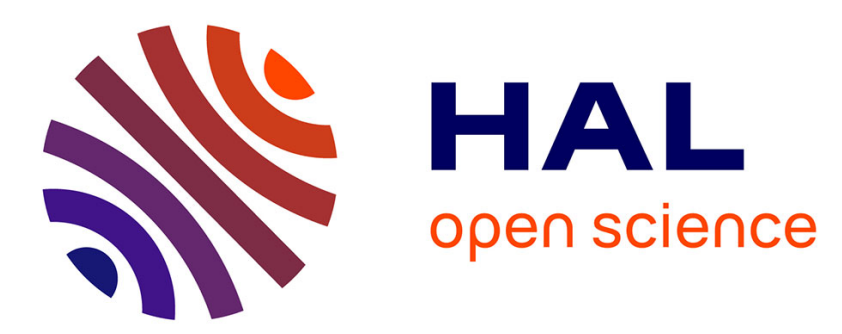

\title{
Did the Quaternary climatic fluctuations really influence the tempo and mode of diversification in European rodents?
}

Christelle Tougard

\section{- To cite this version:}

Christelle Tougard. Did the Quaternary climatic fluctuations really influence the tempo and mode of diversification in European rodents?. Journal of Zoological Systematics and Evolutionary Research, 2017, 55 (1), pp.46 - 56. 10.1111/jzs.12152 . hal-01921408

\section{HAL Id: hal-01921408 \\ https://hal.umontpellier.fr/hal-01921408}

Submitted on 30 Nov 2020

HAL is a multi-disciplinary open access archive for the deposit and dissemination of scientific research documents, whether they are published or not. The documents may come from teaching and research institutions in France or abroad, or from public or private research centers.
L'archive ouverte pluridisciplinaire HAL, est destinée au dépôt et à la diffusion de documents scientifiques de niveau recherche, publiés ou non, émanant des établissements d'enseignement et de recherche français ou étrangers, des laboratoires publics ou privés. 
1 Did the Quaternary climatic fluctuations really influence the tempo and mode of 2 diversification in European rodents?

3

$4 \quad$ Christelle Tougard

5

6 Institut des Sciences de l'Evolution de Montpellier, UMR CNRS-UM-EPHE 5554, IRD 226

7 and CIRAD 117, Université de Montpellier, Place Eugène Bataillon, CC065, 34095

8 Montpellier cedex 05, France; Phone: +33467144717; Fax: +33467143622; e-mail:

9 christelle.tougard@umontpellier.fr

10

11 Key words: Ancestral biogeographic areas - molecular dating - phylogeny - Microtus

12 (Terricola) - speciation

13 


\section{Abstract}

The objective of the present study is to establish if the Quaternary climatic fluctuations 3 influenced the tempo and mode of diversification in European rodents. Our case study is the 4 subgenus Microtus (Terricola) distributed from Western Europe to the Caucasus. 5 Mitochondrial cytochrome $b$ gene sequences from several representatives of all the species 6 were used to generate maximum-likelihood and Bayesian phylogenetic trees, to estimate 7 divergence times, to identify biogeographic ancestral areas and to study the rate of 8 diversification. Results showed that phylogenetic tree topologies were similar to previous 9 published studies but with a better resolution at some nodes. The origin of Microtus 10 (Terricola) is dated back to approximately $4.05 \mathrm{Myr}$ in the Early Pliocene, and molecular 11 dating for most Terricola species corresponds to several glacial periods of the Pleistocene. 12 Results of the biogeographic ancestral area reconstruction suggest that Microtus (Terricola) 13 diversified from the Caucasus/Turkey/Iran area through Western Europe. Several periods of 14 diversity variation were highlighted: two period of diversity increase, between 3 and $2 \mathrm{Myr}$, 15 and after $1 \mathrm{Myr}$; two periods of diversity decrease, before $3 \mathrm{Myr}$, and between 2 and $1 \mathrm{Myr}$. 16 The diversification rate of Microtus (Terricola) was $0.353 \pm 0.004$ event/Myr, a rate similar to 17 that of the Muridae family. To conclude, although the Pleistocene glacial conditions had an impact on the speciation events, the Quaternary does not appear however as a period with an exceptional rate of diversification for European rodents. 


\section{Introduction}

2 Estimating diversification rates appears essential in ecology and evolutionary biology to understand how the biodiversity varies across space and time (Ricklefs 2007; Morlon 2014).

4 Because speciation and extinction processes require thousands to millions of years to happen, 5 diversification has long been studied from fossil data. Since the 1990's, a phylogenetic alternative is commonly used to estimate speciation, extinction, and thus diversification rates because phylogenies contain information about evolutionary relationships among species with a temporal dimension (Hey 1992; Nee et al. 1994; Sanderson and Donoghue 1996; Paradis 1997; Ricklefs 2007; Morlon 2014) and a characteristic signature left by extinction events (Nee 2001; Rabosky 2009). Molecular phylogenies were used to infer diversification rates, for instance, in plants (Magallón and Sanderson 2001; Hughes and Eastwood 2006), insects (Barraclough and Vogler 2002), amphibians (Kozak et al. 2006) and birds (Zink et al. 2004). In mammals, a fluctuating diversification rate since the Cretaceous/Tertiary boundary was recently highlighted (Stadler 2011). Several shifts in diversification rates were even identified in the most diversified mammalian clade, the Rodentia (Steppan et al. 2004; Fabre et al. 2012). Several hypotheses were proposed to explain these shifts as key innovations, biogeographic events, absence of competition or predation, chromosomal rearrangements as well as environmental changes (Rowe et al. 2011; Fabre et al. 2012).

Quaternary climatic fluctuations (during the last 2.6 Myr, Cohen and Gibbard 2012) are thought to have influenced plant and animal distribution through repeated range contraction (population isolation) and expansion (colonization by tracking favourable climatic space). For this reason, they are often considered as a major driving force of allopatric diversification. In particular, the role of Quaternary glacial cycles is often considered to explain the extraordinary diversification of the rodent genus Microtus Schrank, 1798 from the family Cricetidae (Chaline 1987; Chaline et al. 1999; Jaarola et al. 2004). The ancestor of the Microtus species is apparently within species of the genus Allophaiomys Kormos, 1930 (Chaline et al. 1999). Early radiation and diversification about $2.4-2 \mathrm{Myr}$ ago (Early Pleistocene; Chaline and Graf 1988; Chaline et al. 1999; Zheng and Zhang 2000) would have generated Microtus subgenera that subsequently would have led to the appearance of the diverse extant species. One of the most studied radiations from systematic, paleontological, odontometric, cytogenetic, ethological, morphometric or genetic standpoints (e.g. BastosSilveira et al. 2012; Brunet-Lecomte 1988, 1989, 1990; Brunet-Lecomte and Chaline 1990, 1991, 1992; Castiglia et al. 2008; Chaline and Graf 1988; Chaline et al. 1988, 1999; Giannoni 
1 et al. 1993; Haring et al. 2000; Jaarola et al. 2004; Kryštufek et al. 1996; Macholán et al. 2 2001; Martínková and Dudich 2003; Martínková and Moravec 2012; Martínková et al. 2004, 3 2007; Meylan 1972; Mitsainas et al. 2009; Rovastos and Giagia-Athanasopoulou 2012; 4 Santos et al. 2009; Storch and Winking 1977; Thanou et al. 2005; Tougard et al. 2008a; Zagorodnyuk 1990) is the radiation of the subgenus Terricola Fatio, 1867 (European ground voles). The oldest fossil remains of Microtus (Terricola) are known from the end of Early Pleistocene (around 0.9 Myr) in Italy and they were attributed to M. (T.) arvalidens Kretzoi, 1958 (Masini and Sala 2007).

The subgenus Microtus (Terricola) is characterized by a "pitymyan rhombus" on the first lower molar, a primitive character found in evolved species of Allophaiomys (Chaline et al. 1999). First grouped with some Nearctic voles under the subgenus M. (Pitymys) McMurtrie, 1831, evolutionary studies and phylogenetic analyses underlined that the European ground voles are closer to European M. (Microtus) than to the American subgenera (Graf, 1982; Chaline et al. 1988; Jaarola et al. 2004; Martínková and Moravec 2012; Robovský et al. 2008). Indeed, although Palearctic and Nearctic ground voles seem to share the same Allophaiomys ancestor, they evolved independently leading to two monophyletic subgenera, respectively M. (Terricola) and M. (Pitymys) (Chaline et al. 1988, 1999). If the phylogenetic position of the European ground voles within the Arvicolinae is now clearly established (Jaarola et al. 2004; Martínková and Moravec 2012; Robovský et al. 2008), attempts to reconstruct phylogenetic relationships among M. (Terricola) from molecular markers have failed maybe because of the dataset incompleteness: mitochondrial cytochrome $b$ gene (cytb) sequences of one or several individuals but not all species represented (Jaarola et al. 2004; Robovský et al. 2008); concatenated supermatrix (72.8\% of missing data) of mitochondrial (cytb, control region, cytochrome $c$ oxidase subunit I and NADH dehydrogenase subunit 4) and nuclear (interphotoreceptor retinoid-binding protein, growth hormone receptor, exon 10, sex-determining region $\mathrm{Y}$ and lecithin cholesterol acyl transferase, exons 2-5) markers for one individual of each species (Martínková and Moravec 2012).

According to Ricklefs (2007), using phylogenetic information to estimate diversification rates depends on three assumptions: the completeness of the phylogenetic data, a reliable time scale and the constancy of speciation and extinction rates through all clades. Because of their high specific diversity (14 extant and 11 extinct species; Brunet-Lecomte 1990; Brunet-Lecomte et al. 1992; Gil 1996; Kowalski 2001; Musser and Carleton 2005), 
and Carleton 2005), the knowledge of their fossil record and their evolutionary history rooted

2 in the Quaternary (Chaline and Graf 1988; Chaline et al. 1999; Zheng and Zhang 2000), the

3 European ground voles are a species group particularly suitable to understand if and how the

4 climatic fluctuations of the Quaternary could have promoted the diversification of rapid

5 evolving small mammals such as rodents in temperate zones. In other words, does the level of

6 diversification during this period exceed other mammal rates? In this context, the aim of the

7 present study is as follows: to investigate the phylogenetic framework of the diversification

8 from sequences of multiple representatives of all the Microtus (Terricola) species, and

9 subspecies when sequences were available; to identify the origin of the diversification; to

10 estimate the rate of diversification. For simplicity, the present study follows the systematic

11 designation of Musser and Carleton (2005), and when dealing with the species, it refers to the

12 genus (Microtus or M.) rather than the subgenus name (Microtus or Terricola), and to

13 Terricola rather than Microtus (Terricola) when dealing with the subgenus.

\section{Material and Methods}

\section{Data}

18 Our dataset included original (15) and GenBank (85) DNA sequences for 100 specimens 19 representing all the Microtus (Terricola) species (according to Musser and Carleton 2005) 20 and some Microtus (Microtus) species, these latter being used as outgroup (Table 1). For 21 original data, total DNA was extracted from $96 \%$ ethanol-preserved tissue pieces (skin or 22 foot) following standard procedures (Sambrook et al. 1989). The complete cytochrome $b$ gene 23 (cytb) was PCR-amplified $\left(\mathrm{Tm}=50^{\circ} \mathrm{C}\right)$ with universal primers located in the flanking tRNAs 24 (L7 5'-ACCAATGACATGAAAAATCATCGTT-3' ${ }^{\prime}$ and H6 5'25 TCTCCATTTCTGGTTTACAAGAC-3'). Direct sequencing was performed in both 26 directions to confirm polymorphic sites by Macrogen Inc (Seoul, Korea). Original and 27 GenBank sequences were aligned by hand using MEGA v5.2.2 (Tamura et al. 2011). Details 28 about the sampling and sequences are in Fig. 1 and Table 1.

\section{Phylogenetic inference}

31 Phylogenetic trees were reconstructed using a maximum-likelihood approach (ML) and a 32 Bayesian inference (BI) through the technical facilities of the Platform Montpellier 33 Bioinformatics Biodiversity (MBB) of the "Institut des Sciences de l'Evolution de 
1 Montpellier" (Centre Méditerranéen de l'Environnement et de la Biodiversité, Montpellier,

2 France; ISEM and CeMEB). Best-fitting models of nucleotide substitution were determined 3 using MrModeltest v2.3 (Nylander 2004). The optimal fitted model in both cases is identified 4 by the minimum value of the Akaike Information Criterion.

ML reconstruction was conducted using PhyML v3.0 (Guindon et al. 2010) under the GTR model (Yang 1994) with a proportion of invariable sites (I) and a gamma distribution (G). Nodal robustness was estimated by bootstrap percentage values (BP) after 1000 pseudoreplicates. In BI, a mixed model analysis was applied according to the cytb codon positions: (1) and (2) HKY (Hasegawa et al. 1985) $+\mathrm{I}+\mathrm{G}$; (3) GTR+I+G. Five independent runs of five Markov chain Monte Carlo (MCMC) chains were simultaneously carried out for 5,000,000 generations using MrBayes v3.1.2 (Ronquist and Huelsenbeck 2003). Bayesian posterior probabilities (PP) were obtained from the $50 \%$ majority rule consensus of trees sampled every $100^{\text {th }}$ generation after a burn-in stage of 25,000 .

Alternative hypotheses of intra-Terricola relationships were compared with the test of Shimodaira and Hasegawa (1999) as implemented in PAUP*4.010b (Swofford 2002).

Intra- and intergroup genetic distances were estimated by the Kimura-2-parameter distance (K2P; Kimura 1980) with MEGA. An internal branch test was performed also with MEGA to determine whether short internal branches in the phylogeny are solved relationships or polytomies. A neighbour-joining distance-based method was used to build a tree under the K2P nucleotide substitution model.

\section{Divergence time estimates}

Time to the most recent common ancestor (TMRCA) was estimated for several clades, and especially each Terricola species, by a Bayesian coalescent analysis under the GTR $+\mathrm{I}+\mathrm{G}$ model with BEAST, v2.3.1 (Bouckaert et al. 2014). Through the technical facilities of the Platform MBB of ISEM (CeMEB), divergence time estimates were achieved under the recently introduced "fossilized birth-death" (FBD) process (Heath et al. 2014). The FBD model considers the diversification of extant and fossil species are part of the same macroevolutionary process. Four parameters (speciation, extinction and fossilization rates as well as proportion of sampled extant species) are taken into account to inform the amount of temporal uncertainty associated with speciation events on the tree (Heath et al. 2014). Three molecular clocks (strict, relaxed uncorrelated lognormal or relaxed uncorrelated exponential) were compared using Bayes factor values $(\mathrm{BF})$ to test which of them best fit our data. BF 
1 consisted of five independent runs of 20 million generations with the first $10 \%$ discarded as

2 burn-in. Results of these five independent runs were combined with LogCombiner v2.3.1

3 (Bouckaert et al. 2014) to estimate TMRCA and 95\% confidence intervals. A consensus tree

4 was generated using TreeAnnotator v2.3.1 (Bouckaert et al. 2014) with mean node heights as node heights option and maximum clade credibility as target tree type option.

The literature regarding the evolutionary history of the subgenus Terricola is rich but full of temporal inaccuracies (a time period such as, for instance, the Cromerian or the Middle Pleistocene in Brunet-Lecomte 1990, Kowalski 2001; a relative dating as, for instance, in Cuenca- Bescós et al. 2010, Masini et al. 2005, Masini and Sala 2007; rarely an absolute dating as in Bonfiglio et al. 2008) or contradictory relationships (notably for the phylogenetic position of Allophaiomys or for the relationships between extinct and extant species as in Chaline, 1987, Chaline et al., 1999). For these reasons, only the dates of $0.800 \pm 0.100 \mathrm{Myr}$ for the occurrence of the ancestor of M. subterraneus, i.e. M. arvalidens (Kowalski 2001; Masini et al. 2005; Masini and Sala 2007; Cuenca- Bescós et al. 2010), as well as the date of $0.475 \pm 0.025$ Myr for the origin of M. arvalis (Miesenheim I, Germany; Kowalski 2001) were used as fossil node and tip calibration points, respectively.

\section{Identification of the ancestral area and diversification rate}

Present-day distribution range (Fig. 1) of Terricola was divided into 11 biogeographic areas, based on the occurrence of one or more Terricola species (Austria, the Balkans, the Carpathians, the Caucasus/Turkey/Iran area, France, Germany/Bavaria, Italy, Portugal, Spain, Switzerland and eastern Europe). The possible ancestral areas of the Terricola main clades were then reconstructed using the Statistical Dispersal-Vicariance Analysis method (S-DIVA; Yu et al. 2010) implemented in RASP v2.1b (Yu et al. 2012) from 2,000 trees obtained from the five combined BEAST runs.

Diversification rates were estimated using BayesRate v1.63b (Silvestro et al. 2011) and BEAST. With BEAST, the analysis was performed simultaneously with the divergence time estimates as previously mentioned on a dataset including the outgroup. To evaluate the accumulation of lineages through time (LTT), a LTT plot was constructed with Tracer1.6 (Rambaut et al. 2014). With BayesRate, marginal likelihoods via the thermodynamic integration were calculated to select the best-fitting model of diversification between the pure-birth or birth-death processes, under the following parameters: 100,000 MCMC iterations per five chains for 1,000 randomly subsampled posterior BEAST trees excluding 
1 the outgroup. Marginal likelihoods were then compared using Bayes factor tests as previously

2 mentioned. Speciation $(\lambda)$, extinction $(\mu)$ and diversification $(\lambda-\mu)$ rates through time were

3 finally estimated with the selected model and previously mentioned parameters. The results

4 were checked using Tracer.

5

$6 \quad$ Results

7

\section{Sequence analysis and phylogenetic reconstructions}

9 The alignment of the complete cytb was 1143 nucleotides long with 348 phylogenetically 10 informative sites (368 with the outgroup). The new sequences were deposited in the EMBL

11 Nucleotide Sequence Database under the accession numbers LT222298-LT222312. Base composition ( $\mathrm{A}=31 \%, \mathrm{C}=29 \%, \mathrm{G}=13 \%, \mathrm{~T}=27 \%$ ) was quite similar to that of other rodents (Martin et al. 2000; Lecompte et al. 2002; Montgelard et al. 2002), and especially Microtus rodents (Conroy and Cook 1999; Tougard et al. 2008). This indicated that no artificial cluster occurred due to a misleading compositional signal in the dataset.

Phylogenetic reconstructions provided similar tree topologies in ML (Fig. 2 with BP and PP robustness values) and BI (data not shown). The monophyly of the subgenus Terricola is highly supported in both approaches $(\mathrm{BP}=98 \%$; $\mathrm{PP}=1.00)$. Among Terricola, all the species are also supported with high values $(88 \%<\mathrm{BP}<100 \%$; $0.96<\mathrm{PP}<1.00)$. Four internal nodes characterized by short branches remain unsolved as in previously published studies (Jaarola et al. 2004; Martínková and Moravec 2012). The internal branch test indicates that these branches are significantly different from zero with length confidence probabilities higher than 95\% (data not shown; Nei and Kumar 2000; Tamura et al. 2011). On the other hand, some nodes, not supported in previously published studies (Jaarola et al. 2004; Martínková and Moravec 2012; Robovský et al. 2008), are here moderately or highly supported: the position of M. majori as the first offshoot of the Terricola species (BP $=98 \%$; $\mathrm{PP}=1.00)$; the cluster of $M$. gerbei with $M$. duodecimcostatus and $M$. lusitanicus $(\mathrm{BP}=60 \%$; PP $=0.87)$. As in Castiglia et al. (2008), M. savii appeared paraphyletic because of the internal position of $M$. brachycercus in this group $(\mathrm{BP}=100 \%$; $\mathrm{PP}=1.00)$. The present study

30 also confirmed that $M$. tatricus belongs to the subgenus Terricola as suggested by several authors (Chaline et al. 1988; Jaarola et al. 2004; Martínková and Moravec 2012), and that $M$. schelkovnikovi does not seem to be a Terricola species. 
The intra-Terricola relationships from the present ML tree topology (Fig. 2) were compared with the intra-Terricola relationships presented in Martínková and Moravec (2012) with the test of Shimodaira and Hasegawa (1999). The best ML tree is the tree presented in Fig. 2. However, the tree topology from Martínková and Moravec (2012) is not significantly worse at the $5 \%$ confidence level $(P=0.076)$. These trees differ by the position of M.majori as the sister group of all the Terricola species (present study) or of the daghestanicus / subterraneus clade (Martínková and Moravec 2012), as well as the position of M. thomasi and M.tatricus as the sister group of either M.felteni or the multiplex complex.

Genetic distances were estimated within and between Terricola species or subspecies (Table S1). Intragroup distances are from $0.1 \pm 0.1 \%$ for $M$. thomasi atticus to $2.8 \pm 0.4 \%$ for M. daghestanicus, while intergroup distances are from $0.8 \pm 0.3 \%$ (M. thomasi atticus $/ M$. thomasi evia) to $12.6 \pm 1.5 \%$ (M. brachycercus $+M$. savii niethammericus/M.daghestanicus).

\section{Molecular dating, biogeographic history and diversification rates}

Likelihood differences suggested that the relaxed uncorrelated lognormal clock is significantly more adapted to our dataset $(2 \operatorname{lnBF}>10)$. For this reason, divergence times for TMRCA in the subgenus Terricola were estimated under a lognormal molecular clock and the fossilized birth-death process. Convergence to stable values was checked with Tracer 1.6, obtaining an effective sample size (ESS) greater than 200 for all parameters. Divergence times are provided in Fig. 3. The origin of this subgenus is dated back to approximately 4.05 Myr in the Early Pliocene, and molecular dating for most Terricola species corresponds to several glacial periods of the Pleistocene: from 1.81 Myr for the savii complex to $0.08 \mathrm{Myr}$ for M. majori. In this context, the substitution rate is estimated at $0.033 \pm 0.004$ substitution / site / Myr which seems lower than the rate (0.08) estimated for the genus Microtus (represented by M. levis and M. kikuchii Kuroda, 1920) but closer to that of others rodent genera such as Mus Linnaeus, 1758, Rattus Fisher, 1903, Ctenomys Blainville, 1826 and Chaetopidus Merriam, 1889 (Triant and DeWoody 2006).

Results of the ancestral area reconstructions with RASP are presented in Fig. 3. S-DIVA suggests that the subgenus Terricola most likely diversified early in the Caucasus/Turkey/Iran area (CTI in Fig. 3; frequency of occurrence $=100 \%$ ). Subsequently, multiple dispersal (7) and vicariance (5) events occurred. Within the CTI area, two clades diverged giving rise to M. majori and the clade containing all the other Terricola species with an ancestor distribution including the CTI area and Southern Europe (100\%). With an 
1 daghestanicus and M. subterraneus; Italy for the savii complex; Spain + France for M. gerbei,

$2 M$. lusitanicus and M. duodecimcostatus; the Balkans for M. felteni and M. thomasi; the 3 Carpathians for $M$. tatricus. The biogeographic history of the multiplex complex (M. 4 multiplex, M. liechtensteini and M. bavaricus) is much more difficult to interpret with Italy, 5 the Balkans, France, Switzerland and/or Austria as possible ancestral area.

In diversification estimates, BF values provided a strong support $(2 \ln B F>10)$ for the birth-death process. The diversification rate detected for this model was $0.353 \pm 0.004(\lambda=$ $5.767 \pm 0.033$ and $\mu=5.414 \pm 0.031)$ and $0.483 \pm 0.051$ event/Myr with BayesRate and BEAST, respectively. The LTT plot (Fig. 4) reflects two periods of diversity increase (between 3 and $2 \mathrm{Myr}$, and after $1 \mathrm{Myr}$ ) and decrease (before $3 \mathrm{Myr}$, and between 2 and 1 11 Myr).

\section{Discussion}

\section{Phylogenetic framework of the diversification}

16 From a molecular standpoint, the phylogeny of the subgenus Terricola was never studied for itself but it was always studied in a larger context, i.e. included in the phylogeny of the Arvicolinae or of the genus Microtus (Jaarola et al. 2004; Martínková and Moravec 2012; Robovský et al. 2008). For this reason, its evolutionary history was never deeply investigated. The use of only cytb sequences should be seen as a limitation of the study. Nevertheless, our phylogeny based on a single mitochondrial marker but including several representatives of all the Terricola species appears better resolved.

As in previously published studies, the present study confirms the monophyly of the subgenus Terricola. Several clusters are not questionable, notably the multiplex complex (Haring et al. 2000; Jaarola et al. 2004; Martínková and Moravec 2012; Robovský et al. 2008). The cluster composed of M. subterraneus and M.daghestanicus is also always highly supported, although Macholán et al. (2001) suggested the paraphyly of M. subterraneus with M. majori and M. daghestanicus from karyotypic and allozymic data. Regarding the savii complex, three clades (M. s. savii, M. s. nebrodensis and M. brachycercus $+M$. s. niethamericus) were identified as in Castiglia et al. (2008). These latter authors suggested first the paraphyly of $M$. savii because of the internal position of $M$. brachycercus, and they then proposed a specific status for both species in considering M. s. niethammericus and $M$. brachycercus as conspecific. As for M. s. nebrodensis, some authors supported the hypothesis 
1 that it is an endemic species of Sicily because of its phylogenetic position in the savii 2 complex and its high morphological, cytogenetic, mitochondrial and nuclear genetic 3 divergence (Castiglia et al. 2008; Bezerra et al. 2015). The cluster of $M$. gerbe $i$ with the clade 4 formed by M.lusitanicus and M.duodecimcostatus is also highly supported, as in Robovský et al. (2008), although Chaline et al. $(1988,1999)$ considered $M$. gerbei as a species of the savii complex from paleontological and morphological data. Lastly, M. schelkovnikovi does not seem to be a Terricola species as proposed by morphological, karyological and molecular studies (Nadachowski 2007; Martínková and Moravec 2012). Nadachowski (2007) even considered this species as the sole member of the subgenus Microtus (Hyrcanicola).

By contrast, the present study strongly supports the position of M. majori at the basis of the Terricola clade, what is in opposition with previous published works (Jaarola et al. 2004; Martínková and Moravec 2012; Robovský et al. 2008) where M. majori is clustered with M. subterraneus and M. daghestanicus but with low supports. Based on its karyotype, Zagorodnyuk (1990) considered besides M. majori as the sole member of its own species complex. An other point of divergence between the present and previously published studies (Jaarola et al. 2004; Martínková and Moravec 2012; Robovský et al. 2008) is the phylogenetic position of M. thomasi and M. tatricus. Regarding M. thomasi, three groups are identified in the present study and they are attributed to three (thomasi, atticus and evia) out of the five $M$. thomasi subspecies, as in Rovatsos and Giagia-Athanasopoulou (2012) but here with better supports. Based on reproductive, cytogenetic and cytb data, these latter authors proposed to consider M.thomasi and M. atticus (including the two "chromosome races" atticus and evia) as separate biological species. In the present study, M. thomasi would be the sister group of the multiplex complex, while M. tatricus would be the sister species of M.felteni. It is the opposite situation in previously published studies (Jaarola et al. 2004; Martínková and Moravec 2012; Robovský et al. 2008), but, in any case, relationships are poorly supported. No information in the literature can support a hypothesis rather than the other, except maybe the geographic proximity of M.thomasi and M.felteni in the Balkans (Mitchell-Jones et al. 1999; Musser and Carleton 2005; Shenbrot and Krasnov 2005).

Unfortunately, two internal clusters remain not supported among the Terricola species (Fig. 2) and are characterized by short branches. Several studies at generic level recovered polytomies among species, leading some authors to the conclusion of a burst of species diversification with no time left for the accumulation of synapomorphies in mitochondrial 
1 1998). In the present case, the internal branches not supported appear not significantly short

2 that suggests a lack of phylogenetic resolution rather than fast lineage differentiations.

\section{Origin of the diversification}

5 From the fossil record, the evolutionary history of the genus Microtus, and thus of the subgenus Terricola, seems rooted in the Quaternary because the oldest fossil remains attributed to the ancestor of Microtus (i.e. Allophaiomys) are from the Early Pleistocene (2.4 - 2 Myr; Chaline and Graf 1988; Chaline et al. 1999; Zheng and Zhang 2000). However, our molecular dating and ancestral biogeographic reconstruction place the origin of Terricola at the end of the Early Pliocene ( $\approx 4 \mathrm{Myr}$ ) in a region including the Caucasus, Turkey and Iran (CTI; Fig. 3). Indeed, this subgenus shares a common ancestor with the subgenus Microtus (Jaarola et al. 2004; Martínková and Moravec 2012; Robovský et al. 2008) of which most species are distributed in Eastern Europe, Asia Minor and Western Central Asia, including the CTI area (Musser and Carleton 2005; Shenbrot and Krasnov 2005). In this region, the orogenic activity linked to the collision between the Arabian and Eurasian plates was at its acme during the late Miocene-Pliocene and it was accompagnied by a rapid mountain uplift that could potentially lead to the isolation of ancestral Terricola populations (Mosar et al. 2010; Ruban et al. 2007). A vicariant event ( $\approx 3.6 \mathrm{Myr}$ ) seems then at the origin of the split between two ancestral lineages: one including the species of the subterraneus complex and the other leading to all endemic European species. After $3 \mathrm{Myr}$, the progressive global cooling leading to a more suitable composition of the vegetation (from sub-tropical forested environments to temperate broad-leaved deciduous or coniferous forests and boreal vegetation; Fauquette and Bertini 2003; Pross and Klotz 2002; Thompson and Fleming, 1996; Willis et al. 1999) for Terricola species would have allowed the colonization of Europe westwards.

From the Pleistocene climatic records, glacial conditions dominated between the Praetiglian (2.6 - 2.4 Myr) to the Menapian (1.20 - 1.07 Myr) stages (Cohen and Gibbard 2012; De Jong 1988; Vandenberghe 2001). They should be at the origin of the differentiation of ancestral evolutionary lineages in Mediterranean peninsulas (Italy, the Balkans and the Iberian Peninsula; Fig. 3). Indeed, these Mediterranean areas are often considered as glacial refugia and sources of northwards postglacial colonization (Hewitt 1996, 2000, 2004; Taberlet et al. 1998) or as a hotspot of endemism for small mammals (Bilton et al. 1998). In both cases, geographic isolation of small populations in these peninsulas during Pleistocene glaciations could have served as "speciation traps", thus promoting allopatric speciation 
1 events (Chaline 1987). This was notably exemplified by the in situ differentiation of the savii

2 or multiplex complex ancestral lineages in Italy or in the Alps, respectively (Fig. 3). Even if

3 Italy is recognized as a potential glacial refugium, few Italian populations would have

4 participated to postglacial (re)colonization of northern Europe because of the Alps (Hewitt

5 2000; Taberlet et al. 1998), although the Alps are considered either as a barrier to postglacial

6 expansion as for the savii complex species or as a glacial refugium (in southwestern,

7 southeastern and/or northern marginal areas) as for the multiplex complex species (Haring et

8 al. 2000; Hewitt 2000, 2004; Schmitt and Varga 2012).

From the present molecular dating, most extant Terricola species have their origin after the end of the Cromerian interglacial $(\approx 0.5$ Myr; Fig. 3), i. e. during a period characterized by the development of regular and vast North European ice sheets and mountain caps (Böse et al. 2012). This results combined with the evolutionary hypotheses emitted on the ancestral lineages, the knowledge on the origin and present-day restricted geographic distribution (Fig. 1) of these Terricola species suggests that their speciation occurred after a long-term isolation in Mediterranean (Italy, the Balkans and the Iberian Peninsula including Southern France) and extra-Mediterranean (marginal areas of the Alps and the Carpathians, and the Caucasus) glacial refugia (Hewitt 1996, 2000, 2004; Schmitt and Varga 2012; Taberlet et al. 1998) according to an allopatric model. Only M. subterraneus and $M$. daghestanicus seem to have an older origin (respectively, 0.79 and $0.84 \mathrm{Myr}$ ). They probably evolved in situ as suggested by our reconstruction of the biogeographic ancestral areas (Fig. 3) and by Baskevich (1997) for M.daghestanicus. As mentioned previously, M. arvalidens is considered as being the ancestor of M. subterraneus. These two species, the former extinct and the latter extant, were and are the only widespread Terricola species in Europe with a nearly similar geographic distribution. Moreover, the distribution of M. subterraneus seems limited by the interspecific competition (Quéré and Le Louarn 2011), and, for this reason, it could have colonized Europe from the CTI area by replacing M. arvalidens by competitive exclusion (Krause 1986; Futuyma 1997).

Discrepancies exist between molecules and fossils on the origin of the subgenus Terricola and Terricola species. Indeed, the fossil record documents at best the first appearance of a morphologically recognizable group (Allophaiomys or Terricola morphotypes) and not the time when species became genetically isolated (Douzery et al. 2004; Yang 2014). In a way, this situation is comparable with what it is observed with the cryptic species: they are morphologically similar but genetically distinct, and for this reason, 
1 they can have diverged thousand to millions of years ago (for instance, Hulva et al. 2004;

2 Irwin et al. 2001; Šlapeta et al. 2006; Tougard et al. 2013).

3

\section{$4 \quad$ Rate of diversification} mammal species.

The Quaternary climatic fluctuations, and especially the glacial periods, are thought to have an impact on species diversity and distribution of plants and animals. In the present context, most extinct Terricola species originated from the Cromerian interglacial or other later and shorter interglacials but it seems, from the fossil record, they did not survived these periods (Brunet-Lecomte 1989; Cuenca- Bescós et al. 2010; Gil 1996; Kowalski 2001). According to several authors (Dalén et al. 2007; Hewitt 1996; Provan and Bennett 2008; Stewart et al. 2010), populations, with a dispersal ability that does not allow to track retreating habitats when climatic conditions became harsher, went extinct. There is no evidence (no fossil remain) allowing to say that the extinct Terricola species, mostly endemic to some restricted continental or insular localities, migrated southwards when colder climatic conditions occurred nor if there is an ancestor-descendant relation between some of these extinct and extant Terricola species, except for M. arvalidens and M. subterraneus. On the other hand, most extant Terricola species found their origin during glacial periods because of a long-term divergence of ancestral lineages in Mediterranean and extra-Mediterranean glacial refugia thus seen as allopatric speciation traps (Chaline 1987; Haring et al. 2011; Hewitt 2004; Martínková and Moravec 2012). All the extant Terricola species have a relatively recent origin (between 0.84 and $0.08 \mathrm{Myr}$; Fig. 3), while the "lifespan" for some extinct Terricola species is estimated between 0.2 and 0.4 Myr (Brunet-Lecomte 1988). According to Avise et al. (1998), speciation in mammals requires a time frame of $2.2 \pm 1.0 \mathrm{Myr}$, and thus the fossil record and our molecular dating could suggest that the time frame may be too short in voles to achieve complete speciation. Chaline et al. (1999) considered however that the speciation duration in vole species is relatively short, from 0.3 to less than $1.5 \mathrm{Myr}$, compared to other

From the present study, it seems that the Pleistocene glacial conditions had an impact on the speciation and extinction events, but does that mean that the rate of diversification during the Quaternary was heightened? The LTT plot (Fig. 4) underlined several shifts in the Terricola diversification rate with two phases of increase (between 3 and 2 Myr and after 1 Myr), more or less corresponding to periods dominated by cool or cold climate conditions. The estimated rate of diversification for the Terricola species was $0.353 \pm 0.004$ events / Myr. Diversification rates were also estimated for numerous plant and animal groups but rarely at 
1 the subgenus level. In rodents, several shifts in diversification rates were identified (Steppan et al. 2004; Fabre et al. 2012). Seven of these shifts were notably underlined in the Cricetidae (Fabre et al. 2012). Unfortunately, no study focused specifically on diversification rates of this rodent family. With 1.36 events / Myr, the cricetid Akodon of the subfamily Sigmodontinae presents a higher diversification rate than the subgenus Terricola (Leite et al. 2014), whereas Akodon originated at the beginning of the Pleistocene (between 2.65 and 2 Myr; Smith and Patton 2007). It thus presents a diversification rate among the highest reported for vertebrates, that is to say four times higher than that of the subgenus Terricola. This rate for Terricola is rather comparable to the average diversification rate of another rodent family, the Muridae (around 0.36 events / Myr; Stanley 1998). Consequently, the Quaternary does not appear as a period with an exceptional rate of diversification compared to other animal groups, although some periods in the Quaternary appear more favourable for the diversification of this subgenus.

\section{Acknowledgements}

16 I am grateful to all the people who provided us with tissue samples or help us to get them: 17 Armando Nappi (Museo Civico di Storia Naturale, Morbegno, Italy); François Catzeflis (FC; Institut des Sciences de l'Evolution, Montpellier, France); Friederike Spitzenberger (FS; Natural History Museum, Vienna, Austria); Giovanni Boano (GB; Museo Civico di Storia Naturale, Carmagnola, Italy); Jean-Pierre Quéré (JPQ; Centre de Biologie et de Génétique des Populations, Montferriez sur Lez, France); the late Luis Nieder (LN; Dipartimento di Biologia Evolutiva, Parma, Italy); Natalia Martínková (NM; Institute of Vertebrate Biology and Institute of Biostatistics and Analyses, Brno, Czech Republic); Patrick Brunet-Lecomte (PBL; Biogéosciences, Dijon, France). I would like also to thank Daniele Silvestro (Department of Ecology and Evolution, Lausanne University, Switzerland) for analytical help with BayesRate. Claudine Montgelard (Centre d'Ecologie Fonctionnelle et Evolutive, Montpellier, France), Elisabeth Haring (Editor-in-Chief of JZSER) and the reviewers are also warmly thanked for their helpful comments. This work was financially supported by my former and current laboratories (Biogéosciences and ISEM). ISEM n²016-175.

\section{References}

Avise JC, Walker D, Johns GC (1998) Speciation durations and Pleistocene effects on 
1 Barraclough TG, Vogler AP (2002) Recent diversification rates in North American tiger beetles estimated from a dated mtDNA phylogenetic tree. Mol Biol Evol 19: 1706-1716.

Baskevich MI (1997) A comparative analysis of structural features of spermatozoa and karyotypes in three species of shrub voles: Terricola majori, T. daghestanicus and $T$. subterraneus (Rodentia, Cricetidae) from the former USSR. Zool Zh 76: 597-607.

Bastos-Silveira C, Santos SM, Monarca R, Mathias ML, Heckel G (2012) Deep mitochondrial introgression and hybridization among ecologically divergent vole species. Mol Ecol 21: 5309-5323.

Bezerra AMR, Annesi F, Aloise G, Amori G, Giustini L, Castiglia R (2015) Integrative taxonomy of the Italian pine voles, Microtus savii group (Cricetidae, Arvicolinae). Zool Scr DOI: $10.1111 / \mathrm{zsc} .12155$.

Bilton DT, Mirol PM, Mascheretti S, Fredga K, Zima J, Searle JB (1998) Mediterranean Europe as an area of endemism for small mammals rather than a source for northwards postglacial colonization. Proc R Soc Lond B Biol Sci 265: 1219-1226.

Bonfiglio L, Esu D, Mangano G, Masini F, Petruso D, Soligo M, Tuccimei P (2008) Late Pleistocene vertebrate-bearing deposits at San Teodoro Cave (North-Eastern Sicily): preliminary data on faunal diversification and chronology. Quatern Int 190: 26-37.

Böse M, Lüthgens C, Lee JR, Rose J (2012) Quaternary glaciations of northern Europe. Quat Sci Rev 44: 1-25.

Bouckaert R, Heled J, Kühnert D, Vaughan T, Wu CH, Xie D, Suchard MA, Rambaut A, Drummond AJ (2014) BEAST 2: A Software Platform for Bayesian Evolutionary Analysis. PLoS Comput Biol 10: e1003537.

Brandley MC, Schmitz A, Reeder TW (2005) Partitioned Bayesian analyses, partitioned choice, and the phylogenetic relationships of scincid lizards. Syst Biol 54: 373-390.

Brunet-Lecomte P (1988) Les campagnols souterrains (Terricola, Arvicolidae, Rodentia) actuels et fossiles d'Europe occidentale. Unpublished $\mathrm{PhD}$ Thesis, Université de Bourgogne, Dijon, France.

Brunet-Lecomte P (1989) La répartition géographique des campagnols souterrains (Arvicolidae, Rodentia) au Quaternaire en Europe occidentale. Mammalia 53: 605-619.

Brunet-Lecomte P (1990) Liste des espèces de campagnols souterrains d'Europe (Arvicolidae, Rodentia). Mammalia 54: 597-604.

Brunet-Lecomte P, Chaline J (1990) Relations phylogénétiques et évolution des campagnols souterrains d'Europe (Terricola, Arvicolidae, Rodentia). C R Acad Sci Paris, Série II 311: $745-750$. 
1 Brunet-Lecomte P, Chaline J (1991) Morphological evolution and phylogenetic relationships of the European ground voles (Arvicolidae, Rodentia). Lethaia 24: 45-53.

Brunet-Lecomte P, Chaline J (1992) Morphological convergence versus biochemical divergences in the Holarctic ground voles: Terricola and Pitymys (Arvicolidae, Rodentia). N Jb Geol Paläont Mh 12: 721-734.

Brunet-Lecomte P, Nadachowski A, Chaline J (1992) Microtus (Terricola) grafi nov. sp. du Pléistocène supérieur de la grotte de Bacho Kiro (Bulgarie). Géobios 25:505-509.

Castiglia R, Annesi F, Aloise G, Amori G (2008) Systematics of the Microtus savii complex (Rodentia, Cricetidae) via mitochondrial DNA analysis: paraphyly and pattern of sex chromosome evolution. Mol Phylogenet Evol 46: 1157-1164.

Chaline J (1987) Arvicolid data (Arvicolidae, Rodentia) and evolutionary concepts. Evol Biol 21: $237-310$.

Chaline J, Brunet-Lecomte P, Graf JD (1988) Validation de Terricola Fatio, 1867 pour les Campagnols souterrains (Arvicolidae, Rodentia) paléarctiques actuels et fossils. C R Acad Sci Paris, Série III 306: 475-478.

Chaline J, Brunet-Lecomte P, Montuire S, Viriot L, Courant L (1999) Anatomy of the arvicoline radiation (Rodentia): palaeogeographical, paleoecological history and evolutionary data. Ann Zool Fennici 36: 239-267.

Chaline J, Graf JD (1988) Phylogeny of the Arvicolidae (Rodentia): biochemical and paleontological evidence. J Mamm 69: 22-33.

Cohen KM, Gibbard P (2012) Global chronostratigraphical correlation table for the last 2.7 million years. Subcommission on Quaternary Stratigraphy (International Commission on Stratigraphy), Cambridge, England.

Conroy CJ, Cook JA (1999) mtDNA evidence for repeated pulses of speciation within arvicoline and murid rodents. J Mamm Evol 6: 221-245.

Cuenca-Bescós G, Rofes J, López-García JM, Blain H-A, De Marfá RJ, Galindo-Pellicena MA, Bennásar-Serra ML, Melero-Rubio M, Arsuaga JL, Bermúdez de Castro JM, Carbonell E (2010) Biochronology of Spanish Quaternary small vertebrate faunas. Quatern Int 212: 109-119.

Dalén L, Nyström V, Valdiosera C, Germonpré M, Sablin M, Turner E, Angerbjörn A, Arsuaga JL, Götherström A (2007) Ancient DNA reveals lack of postglacial habitat tracking in the arctic fox. Proc Natl Acad Sci USA 104: 6726-6729. 
1 De Jong J (1988) Climatic variability during the past three million years, as indicated by Netherlands. Phil Trans R Soc Lond B 318: 603-617.

Douzery EJP, Snell EA, Bapteste E, Delsuc F, Philippe H (2004) The timing of eukaryotic evolution: does a relaxed molecular clock reconcile protein and fossils? Proc Natl Acad Sci USA 101: 15386-15391.

Fabre PH, Hautier L, Dimitrov D, Douzery EJP (2012) A glimpse on the pattern of rodent diversification: a phylogenetic approach. BMC Evol Biol 12:88.

Fauquette S, Bertini A (2003) Quantification of the northern Italy Pliocene climate from pollen data: evidence for a very peculiar climate pattern. Boreas 32: 361-369.

Fink S, Excoffier L, Heckel G (2006) Mammalian monogamy is not controlled by a single gene. Proc Natl Acad Sci USA 103: 10956-10960.

Futuyma DJ (1997) Evolutionary biology. Sinauer Associates, Inc., Sunderland, Massachusetts.

Galewski T, Tilak MK, Sanchez S, Chevret P, Paradis E, Douzery EJP (2006) The evolutionary radiation of Arvicolinae rodents (voles and lemmings): relative contribution of nuclear and mitochondrial DNA phylogenies. BMC Evol Biol 6: 1-17.

Giannoni SM, Borghi CE, Martínez-Rica JP (1993) Comparing the burrowing behaviour of the Iberian mole voles (Microtus (Terricola) lusitanicus, M. (T.) pyrenaicus and M. (T.) duodecimcostatus). Mammalia 57: 483-490.

Gil E (1996) Terricola atapuerquensis (Arvicolidae, Rodentia) nueva especie en el Pleistoceno medio de Atapuerca (Burgos, España). Geogaceta 20: 250-252.

Graf JD (1982) Génétique biochimique, zoogéographie et taxonomie des Arvicolidae (Mammalia, Rodentia). Rev Suisse Zool 89: 749-787.

Guindon S, Dufayard JF, Lefort V, Anisimova M, Hordijk,W, Gascuel O (2010) New algorithms and methods to estimate maximum-likelihood phylogenies: assessing the performance of PhyML 3.0. Syst Biol 57: 307-321.

Haring E, Herzig-Straschil B, Spitzenberger F (2000) Phylogenetic analysis of Alpine voles of the Microtus multiplex complex using the mitochondrial control region. J Zool Syst Evol Research 38: 231-238.

Haring E, Sheremetyeva IN, Kryukov AP (2011) Phylogeny of Palearctic vole species (genus Microtus, Rodentia) based on mitochondrial sequences. Mamm Biol 76: 258-267.

Hasegawa M, Kishino H, Yano T (1985) Dating the human-ape splitting by a molecular clock of mitochondrial DNA. J Mol Evol 22: 160-174. 
1 Haynes S, Jaarola M, Searle JB (2003) Phylogeography of the common vole (Microtus

arvalis) with particular emphasis on the colonization of the Orkney archipelago. Mol Ecol 12: 951-956.

Heath TA, Huelsenbeck JP, Stadler T (2014) The fossilized birth-death process for coherent calibration of divergence-time estimates. Proc Natl Acad Sci USA 111: e2957-e2966.

Hey J (1992) Using phylogenetic trees to study speciation and extinction. Evolution 46: 627640.

Hewitt GM (1996) Some genetic consequences of ice ages, and their role in divergence and speciation. Biol J Linn Soc 58: 247-276.

Hewitt GM (2000) The genetic legacy of the Quaternary ice ages. Nature 405: 907-913.

Hewitt GM (2004) Genetic consequences of climatic oscillations in the Quaternary. Phil Trans R Soc Lond B Biol Sci 359: 183-195.

Hughes C, Eastwood R (2006) Island radiation on a continental scale: exceptional rates of plant diversification after uplift of the Andes. Proc Natl Acad Sci USA 103: 10334-10339.

Hulva P, Horáček I, Strelkov PP, Benda P (2004) Molecular architecture of Pipistrellus pipistrellus / Pipistrellus pygmaeus complex (Chiroptera: Vespertilionidae): further cryptic species and Mediterranean origin of the divergence. Mol Phylogenet Evol 32: 1023-1035.

Irwin DE, Alström P, Olsson U, Benowitz-Fredericks ZM (2001) Cryptic species in the genus Phylloscopus (Old Worls leaf warblers). Ibis 143: 233-247.

Jaarola M, Martínková N, Gündüz I, Brunhoff C, Zima J, Nadachowski A, Amori G, Bulatova NS, Chondropoulos B, Fraguedakis-Tsolis S, González-Esteban J, López-Fuster MJ, Kandaurov AS, Kefelioğlu H, Mathias ML, Villate I, Searle JB (2004) Molecular 3 phylogeny of the speciose vole genus Microtus (Arvicolinae, Rodentia) inferred from 4 mitochondrial DNA sequences. Mol. Phylogenet Evol 33: 647-633.

Kimura M (1980) A simple method for estimating evolutionary rates of base substitutions 6 through comparative studies of nucleotide sequences. J Mol Evol 16: 111-120.

7 Kowalski K (2001) Pleistocene Rodents of Europe. Folia Quaternaria 72: 1-389.

8 Kozak KH, Weisrock DW, Larson A (2006) Rapid lineage accumulation in a non-adaptative 9 radiation: phylogenetic analysis of diversification rates in eastern North American woodland salamanders (Plethodontidae: Pletodon). Proc R Soc Lond B Biol Sci 273: 5391546.

2 Krause DW (1986) Competitive exclusion and taxonomic displacement in the fossil record: 3 the case of rodents and multituberculates in North America. Rocky Mt Geol 24: 95-117.

4 Kryštufek B, Griffiths HI, Vohralík V (1996) The status and use of Terricola Fatio, 1867 in 
the taxonomy of the Palearctic "pine voles" (Pitymys) (Rodentia, Arvicolinae). Bull Inst R Sci Nat Belg Biol 66: 237-240.

Lecompte E, Granjon L, Peterhans JK, Denys C (2002) Cytochrome b-based phylogeny of the Praomys group (Rodentia, Murinae): a new African radiation? CR Biol 325: 827-840.

Leite RL, Kolokotronis SO, Almeida FC, Werneck FP, Rogers DS, Weksler M (2014) In the wake of invasion; tracing the historical biogeography of the South American cricetid radiation (Rodentia, Sigmodontinae). PLoS One 9: e100687.

Lessa EP, Cook JA (1998) The molecular phylogenetics of tuco-tuco (genus Ctenomys, Rodentia: Octodontidae) suggests and early burst of speciation. Mol Phylogenet Evol 9: 88-99.

Macholán M, Filippucci MG, Zima J (2001) Genetic variation and zoogeography of pine voles of the Microtus subterraneus/majori group in Europe and Asia Minor. J Zool Lond 255: $31-42$.

Magallón S, Sanderson MJ (2001) Absolute diversification rates in angiosperm clades. Evolution 55: 1762-1780.

Martin Y, Gerlach G, Schlötterer C, Meyer A (2000) Molecular phylogeny of European muroid rodents based on complete cytochrome $b$ sequences. Mol Phylogenet Evol 16: $37-$ 47.

Martínková N, Dudich A (2003) The fragmented distribution range of Microtus tatricus and its evolutionary implications. Folia Zool 52: 11-22.

Martínková N, Nová P, Sablina OV, Graphodatsky AS, Zima J (2004) Karyotypic relationships of the Tatra vole (Microtus tatricus). Folia Zool 53: 279-284.

Martínková N, Zima J, Jaarola M, Macholán M, Spitzenberger F (2007) The origin and phylogenetic relationships of Microtus bavaricus based on karyotype and mitochondrial DNA sequences. Folia Zool 56: 39-49.

Martínková N, Moravec J (2012) Multilocus phylogeny of arvicoline voles (Arvicolini, Rodentia) shows small tree terrace size. Folia Zool 61: 254-267.

Masini F, Giannini T, Abbazzi L, Fanfani F, Delfino M, Maul LC, Torre D (2005) A latest Biharian small vertebrate fauna from the lacustrine succession of San Lorenzo (Sant'Arcangelo Basin, Basilicata, Italy). Quatern Int 131: 79-93.

Masini F, Sala B (2007) Large- and small-mammal distribution patterns and chronostratigraphic boundaries from the Late Pliocene to the Middle Pleistocene of the Italian peninsula. Quatern Int 160: 43-56.

Meylan A (1972) Caryotypes de quelques hybrides interspécifiques de Pitymys (Mammalia, 
Rodentia). Experientia 28: 1507-1510.

Mitchell-Jones AJ, Amori G, Bogdanowicz W, Krystufek B, Reijnders PJH, Spitzenberger F, Stubbe M, Thissen JBM, Vohralik V, Zima J (1999) The atlas of European mammals. T \& AD Poyser Ltd, London.

Mitsainas GP, Rovastos MT, Rizou EI, Giagia-Athanasopoulou EB (2009) Sex chromosome variability outlines the pathway to the chromosomal evolution in Microtus thomasi (Rodentia, Arvicolinae). Biol J Linn Soc 96: 685-695.

Montgelard C, Bentz S, Tirard C, Verneau O, Catzeflis FM (2002) Molecular systematics of Sciurognathi (Rodentia): the mitochondrial cytochrome $b$ and 12S rRNA genes support the Anomaluroidea (Pedetidae and Anomaluridae). Mol Phylogenet Evol 22: 220-233.

Morlon H (2014) Phylogenetic approaches for studying diversification. Ecol Lett 18: 508525.

Mosar J, Kangarli T, Bochud M, Glasmacher UA, Rast A, Brunet M-F, Sosson M (2010) Cenozoic-recent tectonics and uplift in the Greater Caucasus: a perspective from Azerbaijan. Geological Society, London, Special Publications 340: 261-280.

Musser GG, Carleton MD (2005) Superfamily MUROIDEA. In: Wilson DE, Reeder DM, (eds), Mammal species of the world - a taxonomic and geographic reference. The Johns Hopkins University Press, Baltimore, MD, pp 894-1531.

Nadachowski A (2007) The taxonomic status of Shelkovnikov's Pine Vole Microtus shelkovnikovi (Rodentia, Mammalia). Acta Zool Cracov 50A: 67-72.

Nee S (2001) Inferring speciation rates from phylogenies. Evolution 55: 661-668.

Nee S, Holmes EC, May RM, Harvey PH (1994) Extinction rates can be estimated from molecular phylogenies. Phil Trans R Soc Lond B Biol Sci 344: 77-82.

Nei M, Kumar S (2000) Molecular Evolution and Phylogenetics. Oxford University Press, New York.

Nylander JAA (2004) MrModeltest v2. Program distributed by the author. Evolutionary Biology Centre, Uppsala University.

Paradis E (1997) Assessing temporal variations in diversification rates from phylogenies: estimation and hypothesis testing. Proc R Soc Lond B Biol Sci 264: 1141-1147.

Pross J, Klotz S (2002) Palaeotemperature calculations from the Praetiglian/Tiglian (PlioPleistocene) pollen record of Lieth, northern Germany: implications for the climatic evolution of NW Europe. Global Planet Change 34: 253-267.

Provan J, Bennett KD (2008) Phylogeographic insights into cryptic glacial refugia. Trends Ecol Evol 23: 564-571. 
1 Quéré JP, Le Louarn H (2011) Les Rongeurs de France - Faunistique et biologie. Editions Quæ, Versailles.

Rabosky DL (2009) Heritability of extinction rates links diversification patterns in molecular phylogenies and fossils. Syst Biol 58:629-640.

Rambaut A, Suchard MA, Xie D, Drummond AJ (2014) Tracer v1.6, Available from http://beast.bio.ed.ac.uk/Tracer.

Ricklefs RE (2007) Estimating diversification rates from phylogenetic information. Trends Ecol Evol 22: 601-610.

Robovský J, Ričánková V, Zrzavý J (2008) Phylogeny of Arvicolinae (Mammalia, Cricetidae): utility of morphological and molecular data sets in a recently radiating clade. Zool Scr 37: 571-590.

Ronquist F, Huelsenbeck JP (2003) MrBayes3: Bayesian phylogenetic inference under mixed models. Bioinformatics 19: 1572-1574.

Rovastos MT, Giagia-Athanasopoulou EB (2012) Taxonomical status and phylogenetic relations between the "thomasi" and "atticus" chromosomal races of the underground vole Microtus thomasi (Rodentia, Arvicolinae). Mamm Biol 77: 6-12.

Rowe KC, Aplin KP, Baverstock PR, Moritz C (2011) Recent and rapid speciation with limited morphological diversity in the genus Rattus. Syst Biol 60: 188-203.

Ruban DA, Zerfass H, Yang W (2007) A new hypothesis of the Greater Caucasus terrane in the Late Palaeozoic-Early Mesozoic based on paleontologic and lithologic data. Trabajos de Geología 27: 19-27.

Sambrook J, Fritsch E, Maniatis T (1989) Molecular cloning. Cold Spring Harbor Laboratory, New York.

Sanderson MJ, Donoghue MJ (1996) Reconstructing shifts in diversification rates on phylogenetic trees. Trends Ecol Evol 11: 15-20.

Santos SM, Mira AP, Mathias ML (2009) Factor influencing large-scale distribution of two sister species of pine voles (Microtus lusitanicus and Microtus duodecimcostatus): the importance of spacial correlation. Can J Zool 87: 1227-1240.

Schmitt T, Varga Z (2012) Extra-Mediterranean refugia: the rule and not the exception? Front Zool 9: 22.

Shenbrot GI, Krasnov BR (2005) An atlas of the geographic distribution of the arvicoline rodents of the world (Rodentia, Muridae: Arvicolinae). Pensoft, Sofia.

33 Shimodaira H, Hasegawa M (1999) Multiple comparisons of log-likelihoods with applications to phylogenetic inference. Mol Biol Evol 16: 1114-1116. 
Silvestro D, Schnitzler J, Zizka G (2011) A Bayesian framework to estimate diversification rates and their variation through time and space. BMC Evol Biol 11: 311.

Šlapeta J, López-García P, Moreira D (2006) Global dispersal and ancient cryptic species in the smallest marine eukaryotes. Mol Biol Evol 23: 23-29.

Smith MF, Patton JL (2007) Molecular phylogenetics and diversification of South American grass mice, genus Akodon. In: Kelt DA, Lessa EP, Salazar-Bravo J, Patton, JL (eds), the quintessential naturalist: honoring the life and legacy of Oliver P. Pearson. University of California Press, Berkeley, Los Angeles, London, pp 827-858.

Stadler T (2011) Mammalian phylogeny reveals recent diversification rate shifts. Proc Natl Acad Sci USA 108: 6187-6192.

Stanley SM (1998) Macroevolution: pattern and process. Johns Hopkins University Press, Baltimore, Maryland.

Steppan SJ, Adkins RM, Anderson J (2004) Phylogeny and divergence-date estimates of rapid radiations in Muroid rodents based on multiple nuclear genes. Syst Biol 53: 533-563.

Stewart JR, Lister AM, Barnes I, Dalén L (2010) Refugia revisited: individualistic responses of species in space and time. Proc R Soc Lond B Biol Sci 277: 661-671.

Storch VG, Winking H (1977) Zur Systematik der Pitymys multiplex-Pitymys liechtensteiniGruppe (Mammalia: Rodentia). Z Saugertierkd 42:78-88.

Swofford DL (2002) PAUP*. Phylogenetic analysis using parsimony (*and other methods), version 4.0b10. Sinauer Associates, Inc., Sunderland, Massachusetts.

Taberlet P, Fumagalli L, Wust-Saucy AG, Cosson JF (1998) Comparative phylogeography and postglacial colonization routes in Europe. Mol Ecol 7: 453-464.

Tamura K, Peterson D, Peterson N, Stecher G, Nei M, Kumar S (2011) MEGA5: Molecular Evolutionary Genetics Analysis using Maximum Likelihood, Evolutionary Distance, and Maximum Parsimony Methods. Mol Biol Evol 28: 2731-2739.

Thanou E, Graguedakis-Tsolis S, Chondropoulos B (2005) mtDNA variation and evaluation of phylogenetic relationships among karyotypically polymorphic populations of Microtus (Terricola) thomasi (Arvicolidae, Rodentia) from Greece. Biol J Linn Soc 84: 55-68.

Thompson RS, Fleming RF (1996) Middle Pliocene vegetation: reconstructions, paleoclimatic inferences, and boundary conditions for climate modelling. Mar Micropaleontol 27: 27-49. Tougard C, Brunet-Lecomte P, Fabre M, Montuire S (2008a) Evolutionary history of two allopatric Terricola species (Arvicolinae, Rodentia) from molecular, morphological, and palaeontological data. Biol J Linn Soc 93: 309-323. 
1 Tougard C, Renvoisé E, Petitjean A, Quéré JP (2008b) New insight into the colonization processes of the common voles: inferences from molecular and fossil evidence. PLoS One 3: e3532.

Tougard C, Montuire S, Volobouev V, Markova E, Contet J, Aniskin V, Quéré JP (2013) Exploring phylogeography and species limits in the Altai vole (Rodentia: Cricetidae). Biol J Linn Soc 108: 434-452.

Triant DA, DeWoody JA (2006) Accelerated molecular evolution in Microtus (Rodentia) as assessed via complete mitochondrial genome sequences. Genetica 128: 95-108.

Tvrtkovic N, Pavlinic I, Podnar M (2010) Microtus bavaricus discovered in Croatia: Southern refugium or geographical variation? Mamm Biol 75: 561-566.

Vandenberghe J (2001) Permafrost during the Pleistocene in north west and central Europe. In: Paepe R, Melnikov V (eds), Permafrost response on economic development, environmental security and natural resources. Kluwer Academic Publishers, the Netherlands, pp 185-194.

Willis KJ, Kieczkowski A, Crowhurst SJ (1999) 124,000-year periodicity in terrestrial vegetation change during the late Pliocene epoch. Nature 397: 685-688.

Yang Z (1994) Estimating the pattern of nucleotide substitution. J Mol Evol 39: 105-111.

Yang Z (2014) Molecular Evolution: a statistical approach. Oxford University Press, Princeton.

Yu Y, Harris AJ, He XJ (2010) S-DIVA (statistical dispersal-vicariance analysis): a tool for inferring biogeographic histories. Mol Phylogenet Evol 56:848-850.

Yu Y, Harris AJ, He XJ (2012) RASP (Reconstruct Ancestral State in Phylogenies) 2.1b. Available at http://mnh.scu.edu.cn/soft/blog/RASP.

Zagorodnyuk IV (1990) Karyotypic variability and systematics of the Arvicolini (Rodentia) Communication 1. Species and chromosomal numbers. Vestn Zool 2: 26-37.

Zheng S-H, Zhang Z-Q (2000) Late Miocene-Early Pleistocene micromammals from Wenwanggou of Lingtai, Gansu, China. Vertebrat Palasiatic 38: 58-71.

Zink RM, Klicka J, Barber BR (2004) The tempo of avian diversification during the Quaternary. Phil Trans R Soc Lond B 359: 215-220.

\section{$31 \quad$ Figure Legends}


1 Figure 1. Map showing the geographic distribution (1) of the Microtus (Terricola) species

2 according to the IUCN Red List, and the sampling localities (2) for the specimens used in the

3 present study. Details about the localities and/or the samples are in Table 1.

4

5 Figure 2. Maximum-likelihood tree topology reconstructed from cytochrome $b$ gene 6 sequences of Microtus (Terricola) species as well as M. (Microtus) arvalis and M. (M.) levis 7 used as outgroup. Numbers at node are for maximum-likelihood bootstrap values $(\mathrm{BP} \geq 50 \%)$ 8 and Bayesian posterior probabilities $(\mathrm{PP} \geq 0.85)$. Black crosses indicate nodes with $\mathrm{BP}=$ $9100 \%$ and $\mathrm{PP}=1.00$, while grey crosses are for nodes with $\mathrm{BP}<50 \%$ and $\mathrm{PP}=<0.85$. The 10 species names are indicated on the right and are followed by the symbols used in Fig. 1. 11 Details about specimen numbers are given in Table 1.

12

13 Figure 3. Chronogram showing the divergence time estimates and the reconstruction of the 14 biogeographic ancestral areas. Values in bold and under species names (at right) reflect the 15 time to the most recent common ancestor and, in brackets, the $95 \%$ confidence interval, while letters (biogeographic areas) and values (occurrence frequencies) in regular are related to the biogeographic ancestral area analysis.

19 Figure 4. Lineages through time plot of all the Microtus species (in- and outgroup included) 20 taken into account in the present study.

\section{List of supporting information}

23

24 Table S1. Genetic distance within and between Microtus (Terricola) species and the 25 outgroup. 


\section{Tables}

2 Table 1. List of taxa used in the present analyses. Systematic arrangement is from Musser and 3 Carleton (2005). Sample localities, GenBank accession numbers and author references are 4 indicated for each cytochrome $b$ gene sequence. Locality numbers are for sample numbers of 5 the Fig. 2. Letters in regular are for published data (see the footnote below the table for 6 details), whereas letters in bold are the initials of the tissue providers (see details in 7 acknowledgements).

8

\begin{tabular}{|c|c|c|c|}
\hline Species (Common Name) & Sample Locality & $\begin{array}{c}\text { Accession } \\
\text { Number }\end{array}$ & Source \\
\hline
\end{tabular}

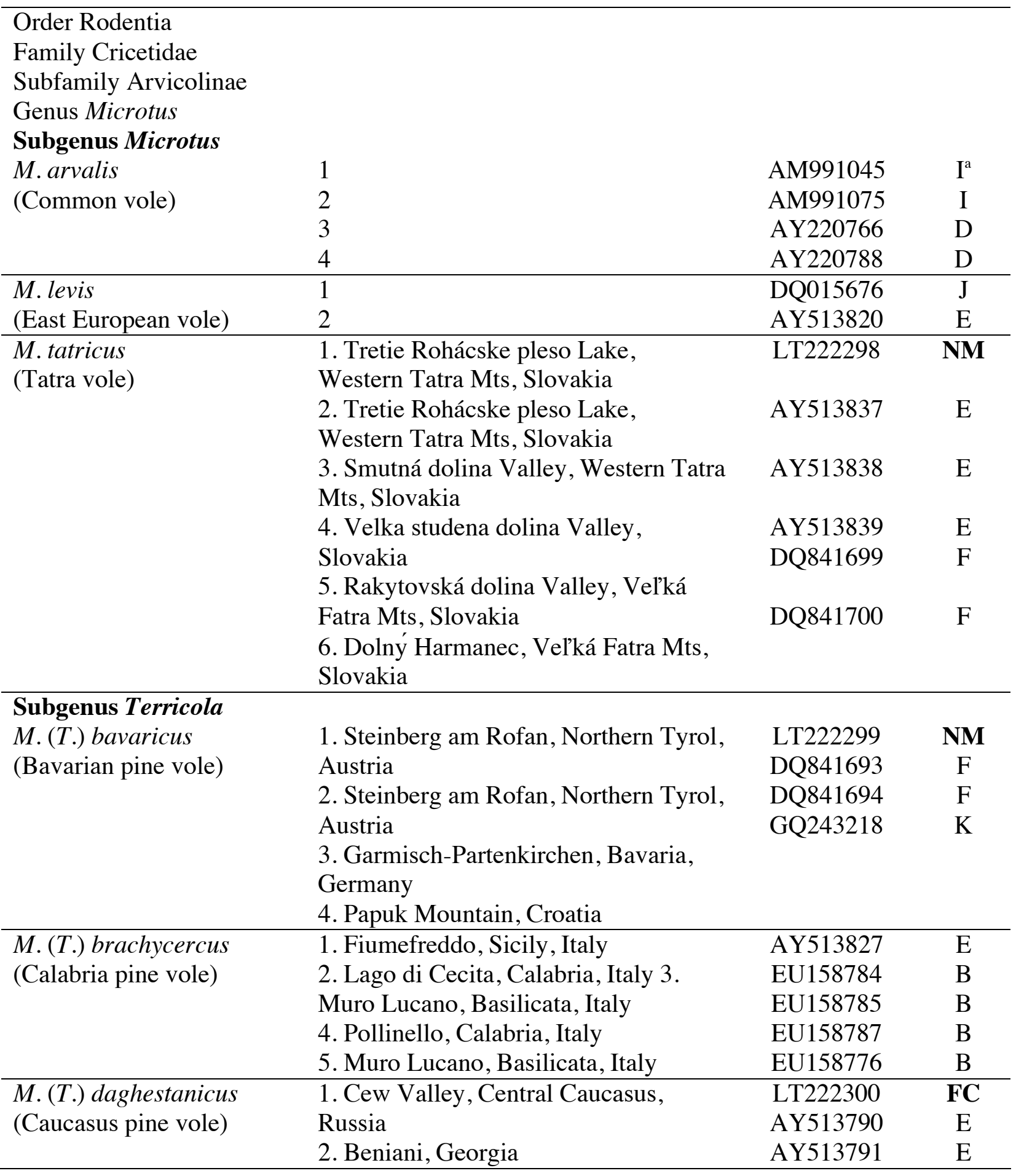




\begin{tabular}{|c|c|c|c|}
\hline & $\begin{array}{l}\text { 3. Bagdasan, Turkey } \\
\text { 4. Handere, Turkey }\end{array}$ & AY513792 & $\mathrm{E}$ \\
\hline \multirow{6}{*}{$\begin{array}{l}\text { M. (T.) duodecimcostatus } \\
\text { (Mediterranean pine vole) }\end{array}$} & 1. Jardin des Gardes, Hautes-Alpes, & LT222301 & JPQ \\
\hline & France & AJ717744 & I \\
\hline & 2. Montferrier, Hérault, France & AY513796 & $\mathrm{E}$ \\
\hline & 3. Setubal, Portugal & AY513797 & $\mathrm{E}$ \\
\hline & 4. Algarve, Portugal & JX424211 & A \\
\hline & 5. Segovia, Spain & & \\
\hline \multirow[t]{2}{*}{$\begin{array}{l}\text { M. }(T .) \text { felteni } \\
\text { (Balkan pine vole) }\end{array}$} & $\begin{array}{l}\text { 1. Mt Pelister, Begova Cesma, } \\
\text { Macedonia }\end{array}$ & AY513798 & $\mathrm{E}$ \\
\hline & 2 & DQ663661 & $\mathrm{C}$ \\
\hline M. (T.) gerbei & 1. Vall d'Aran, Catalogna, Spain & AJ717748 & I \\
\hline \multirow{4}{*}{ (Pyrenean pine vole) } & 2. Armendarits, Pays Basque, France & LT222302 & JPQ \\
\hline & 3. Vall d'Aran, Catalogna, Spain & AY513799 & $\mathrm{E}$ \\
\hline & 4. Riba, Spain & AY513800 & $\mathrm{E}$ \\
\hline & 5. Hecho, Spain & AY513801 & $\mathrm{E}$ \\
\hline \multirow{4}{*}{$\begin{array}{l}\text { M. (T.) liechtensteini } \\
\text { (Liechtenstein's pine vole) }\end{array}$} & 1. Brikini, Slovenia & LT222303 & FS \\
\hline & $\begin{array}{l}\text { 2. Campo di Mezzo, Pian del } \\
\text { Cansiglio, Veneto, Italy }\end{array}$ & LT222304 & LN \\
\hline & 3. Anhovo, Slovenia & AY513811 & $\mathrm{E}$ \\
\hline & 4. Croatia & EF379100 & $\mathrm{F}$ \\
\hline \multirow{8}{*}{$\begin{array}{l}\text { M. (T.) lusitanicus } \\
\text { (Lusitanian pine vole) }\end{array}$} & 1. Saint-Pée-sur-Nivelle, Pays Basque, & AJ717746 & $\mathrm{I}$ \\
\hline & France & LT222305 & JPQ \\
\hline & 2. Saint-Pée-sur-Nivelle, Pays Basque, & AY513812 & $\mathrm{E}$ \\
\hline & France & AY513813 & $\mathrm{E}$ \\
\hline & 3. Burgos, Spain & JX424207 & A \\
\hline & 4. Melgar de Fernamental, Spain & JX424208 & A \\
\hline & 5. Rebordelo, Portugal & & \\
\hline & 6. Grijo da Para, Portugal & & \\
\hline \multirow{3}{*}{$\begin{array}{l}\text { M. (T.) majori } \\
\text { (Major's pine vole) }\end{array}$} & 1. Damar, Turkey & AY513814 & $\mathrm{E}$ \\
\hline & 2. Damar, Turkey & DQ841703 & $\mathrm{F}$ \\
\hline & 3. Hopa, Turkey & DQ841704 & $\mathrm{F}$ \\
\hline \multirow{6}{*}{$\begin{array}{l}\text { M. (T.) multiplex } \\
\text { (Alpine pine vole) }\end{array}$} & 1. Saint Jean de Vaulx, Isère, France & LT222306 & PBL \\
\hline & 2. Carmagnola, Piedmont, Italy & LT222307 & GB \\
\hline & 3. Saint Martin de la Cluze, Isère, & AJ717747 & I \\
\hline & France & AY513817 & $\mathrm{E}$ \\
\hline & 4. Lillaz, Italy & AY513818 & $\mathrm{E}$ \\
\hline & 5. Méribel, France & & \\
\hline \multicolumn{4}{|l|}{ M. (T.) savii (Savi's pine } \\
\hline vole) & 6. Palumbara, Sabina, Latium, Italy & LT222308 & $\mathbf{N M}$ \\
\hline \multirow[t]{6}{*}{ M. (T.) s. savii } & 7. Viterbo, Lazio, Italy & AY513824 & $\mathrm{E}$ \\
\hline & 8. Torino, Piedmont, Italy & AY513825 & $\mathrm{E}$ \\
\hline & 9. Cerano, Piedmont, Italy & AY513826 & $\mathrm{E}$ \\
\hline & 10. Velletri, Italy & EU158777 & B \\
\hline & 11. Circeo, Italy & EU158778 & B \\
\hline & 12. Capracotta, Molise, Italy & EU158780 & B \\
\hline \multirow[t]{4}{*}{ M. (T.) s.niethammericus } & 13. Capracotta, Molise, Italy & EU158781 & $\mathrm{B}$ \\
\hline & 14. Capracotta, Molise, Italy & EU158782 & B \\
\hline & 15. Farindola, Italy & EU158790 & B \\
\hline & 16. Farindola, Italy & EU158791 & $\mathrm{B}$ \\
\hline
\end{tabular}




\begin{tabular}{|c|c|c|c|}
\hline \multirow[t]{4}{*}{ M. (T.) s. nebrodensis } & 17. Ficuzza, Sicily, Italy & EU158802 & B \\
\hline & 18. Ficuzza, Sicily, Italy & EU158804 & $\mathrm{B}$ \\
\hline & 19. Ficuzza, Sicily, Italy & EU158803 & $\mathrm{B}$ \\
\hline & 20. Ficuzza, Sicily, Italy & EU158779 & $\mathrm{B}$ \\
\hline $\begin{array}{l}\text { M. (T.) schelkovnikovi } \\
\text { (Schelkovnikov's pine } \\
\text { vole) }\end{array}$ & $\begin{array}{l}\text { Talysh, Hyrkanian reserve, } \\
\text { Azerbaidjan }\end{array}$ & LT222309 & FC \\
\hline M. (T.) subterraneus & 1. Val Piora Ticino, Switzerland & AJ717745 & I \\
\hline \multirow[t]{9}{*}{ (Common pine vole) } & $\begin{array}{l}\text { 2. Úzka dolina Valley, Western Tatra } \\
\text { Mts., Slovakia }\end{array}$ & LT222310 & NM \\
\hline & 3. Tourch, Finistère, France & LT222311 & JPQ \\
\hline & 4. Seli, Greece & AY513832 & $\mathrm{E}$ \\
\hline & 5. Glocknerhaus, Austria & AY513833 & $\mathrm{E}$ \\
\hline & 6. Ciglikara, Turkey & AY513834 & $\mathrm{E}$ \\
\hline & 7. Nova Kapela, Croatia & FR869858 & $\mathrm{G}$ \\
\hline & 8. Brussels, Waterloo, Belgium & FR869862 & $\mathrm{G}$ \\
\hline & 9. Kasperske hory Mts, Czech Republic & FR869878 & $\mathrm{G}$ \\
\hline & 10. Bialowieza, Poland & FR869884 & $\mathrm{G}$ \\
\hline \multicolumn{4}{|l|}{ M. (T.) thomasi (Thomas's } \\
\hline \multirow[t]{13}{*}{ M. (T.) t. thomasi } & 2. Kalavryta, Greece & JN019756 & $\mathrm{H}$ \\
\hline & 3. Kyparissia, Greece & AY513842 & $\mathrm{E}$ \\
\hline & 4. Trebinje, Bosnia and Hezergovina & AY513844 & $\mathrm{E}$ \\
\hline & 5. Ano Kastritsi, Greece & JN019765 & $\mathrm{H}$ \\
\hline & 6. Ano Kastritsi, Greece & JN019766 & $\mathrm{H}$ \\
\hline & 7. Vrodamas, Greece & JN019773 & $\mathrm{H}$ \\
\hline & 8. Strofylia, Greece & JN019775 & $\mathrm{H}$ \\
\hline & 9. Peleta, Greece & JN019778 & $\mathrm{H}$ \\
\hline & 10. Strofylia, Greece & JN019780 & $\mathrm{H}$ \\
\hline & 11. Aigies, Greece & JN019762 & $\mathrm{H}$ \\
\hline & 12. Voutianoi, Greece & JN019763 & $\mathrm{H}$ \\
\hline & 13. Agios Stefanos, Greece & AY513840 & $\mathrm{E}$ \\
\hline & 14. Afidnes, Greece & JN019760 & $\mathrm{H}$ \\
\hline \multirow[t]{4}{*}{ M. (T.) t. atticus } & 15. Afidnes, Greece & JN019761 & $\mathrm{H}$ \\
\hline & 16. Agios Stefanos, Greece & JN019767 & $\mathrm{H}$ \\
\hline & 17. Eretria, Greece & JN019764 & $\mathrm{H}$ \\
\hline & 18. Vasiliko, Greece & JN019768 & $\mathrm{H}$ \\
\hline M. (T.) t. evia & 19. Kimassi, Greece & JN019771 & $\mathrm{H}$ \\
\hline
\end{tabular}

$1{ }^{\mathrm{a}}$ A: Bastos-Silveira et al. (2012); B: Castiglia et al. (2008); C: Fink et al. (2006); D: Haynes et

2 al. (2003); E: Jaarola et al. (2004); F: Martínková et al. (2007); G: Martínková et al. (unpubl.);

3 H: Rovastos and Giagia-Athanasopoulou (2012); I: Tougard et al. (2008b); J: Triant and

4 DeWoody (2006); K: Tvrtkovic et al. (2010). 
Fig. 1

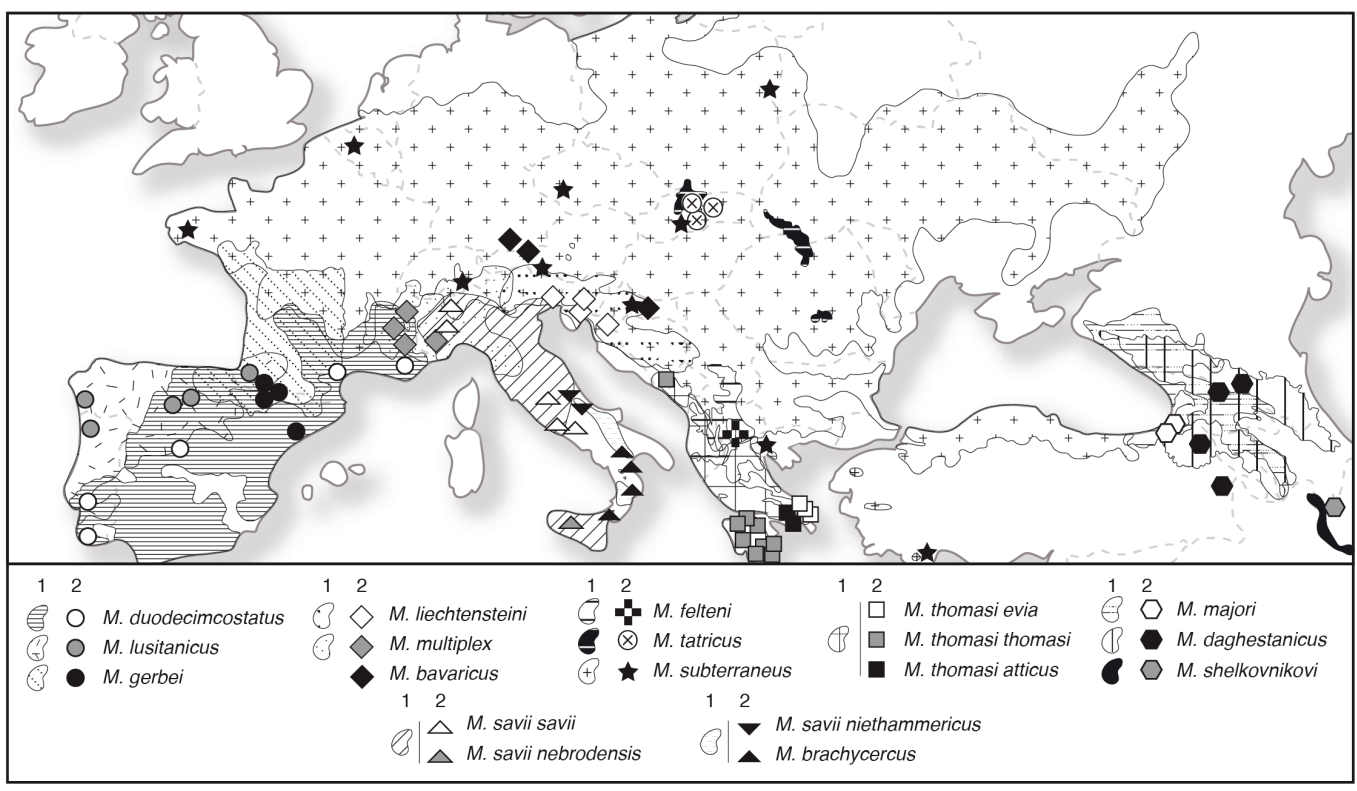


Fig. 2

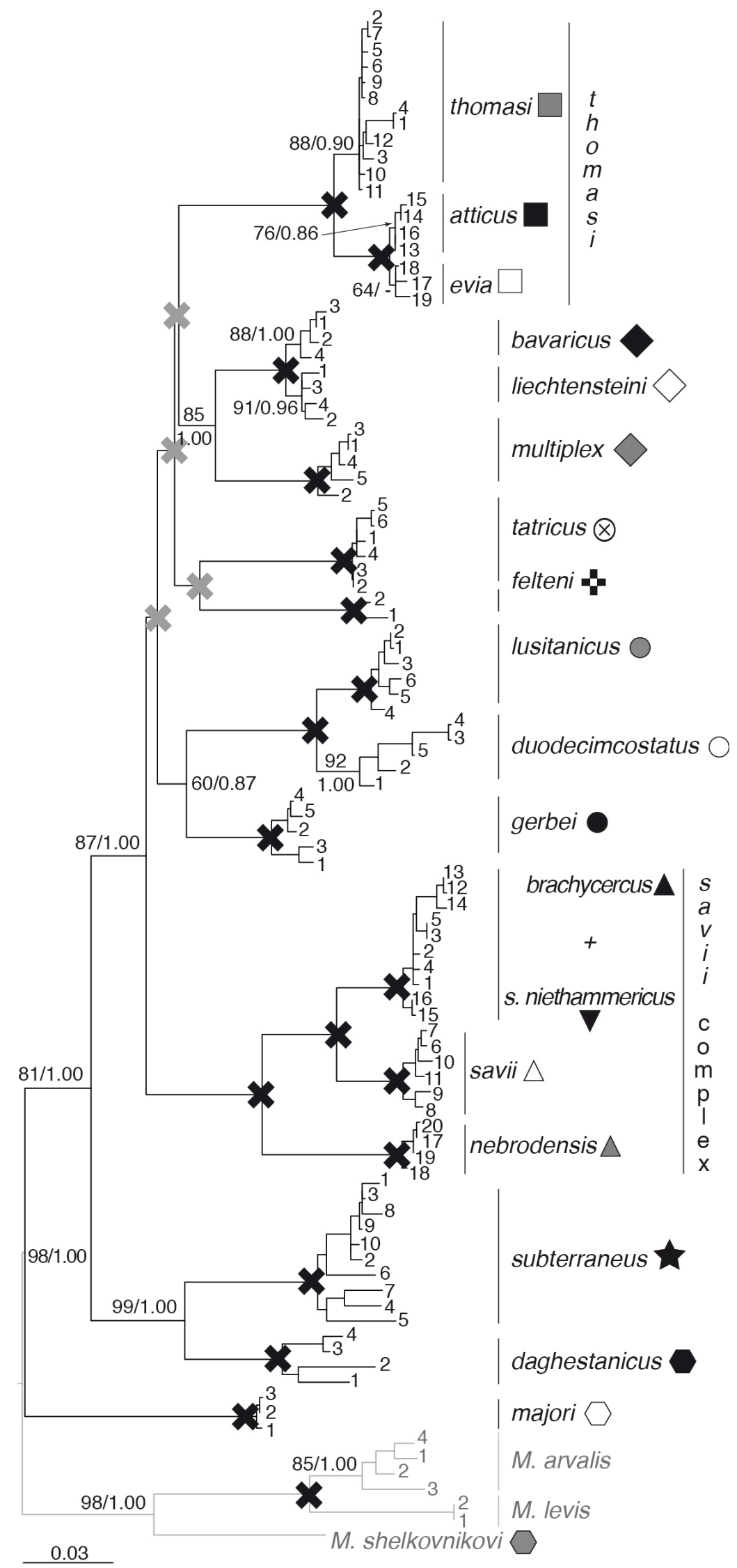


Fig. 3

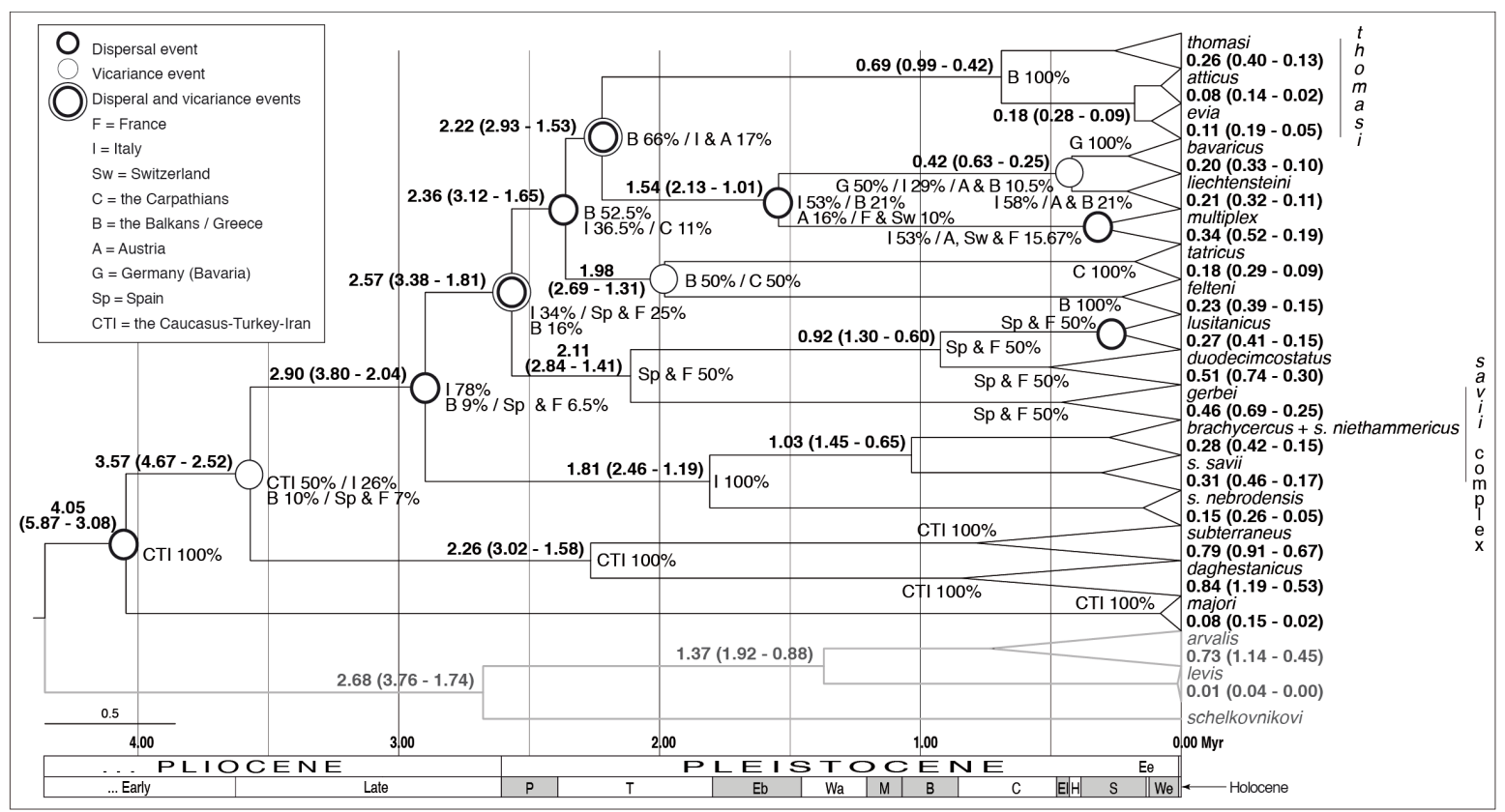


1 Fig. 4

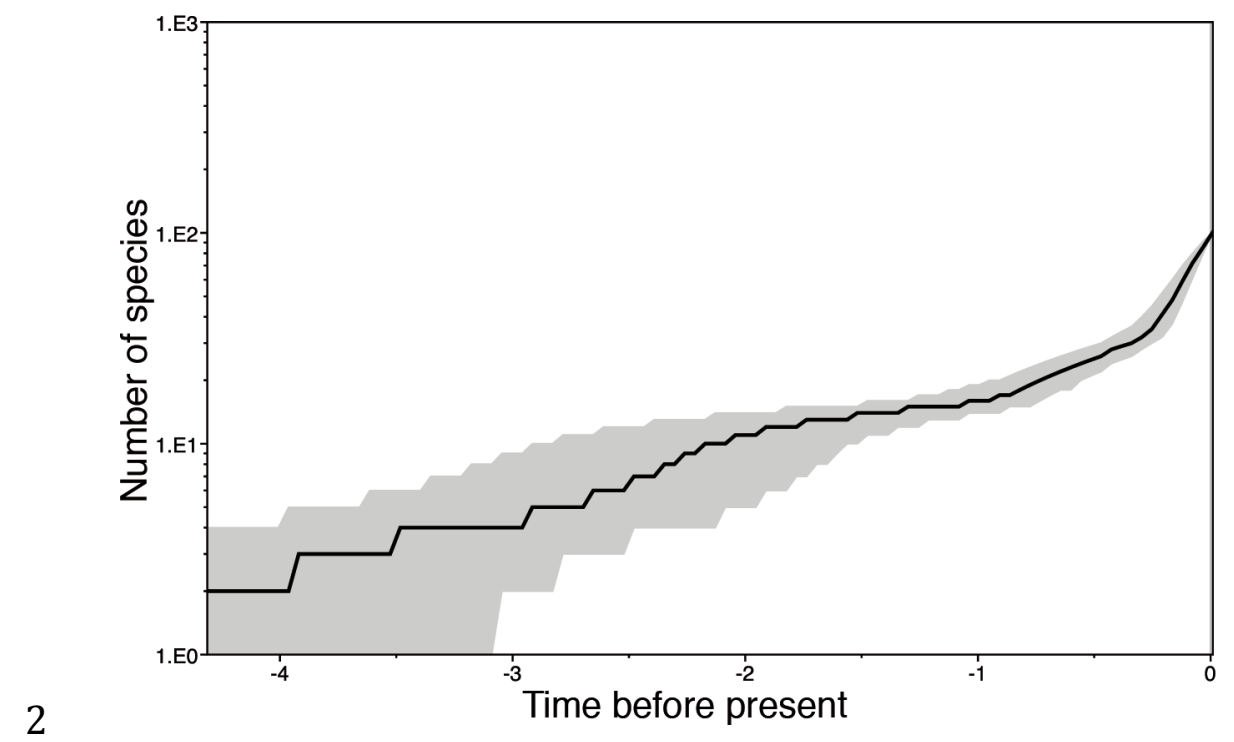


Tableau S1 of C. TOUGARD, Did the Quaternary climatic fluctuations really influence the tempo and mode of diversification in European rodents?

Genetic distance within and between Microtus (Terricola) species and the outgroup

\begin{tabular}{|c|c|c|c|c|c|c|c|c|c|c|c|c|c|c|c|c|c|c|}
\hline & 1 & 2 & 3 & 4 & 5 & 6 & 7 & 8 & 9 & 10 & 11 & 12 & 13 & 14 & 15 & 16 & 17 & 18 \\
\hline 1. majori & $\begin{array}{c}\mathbf{0 . 0 0 2} \\
(\mathbf{0 . 0 0 1})^{\mathrm{a}}\end{array}$ & $0,015^{\mathrm{c}}$ & 0,015 & 0,016 & 0,017 & 0,016 & 0,014 & 0,013 & 0,013 & 0,013 & 0,014 & 0,015 & 0,016 & 0,016 & 0,014 & 0,013 & 0,013 & 0,012 \\
\hline 2. daghestanicus & $0,103^{\mathrm{b}}$ & $\begin{array}{c}0.028 \\
(0.004)\end{array}$ & 0,010 & 0,014 & 0,015 & 0,015 & 0,012 & 0,014 & 0,014 & 0,012 & 0,012 & 0,013 & 0,013 & 0,013 & 0,012 & 0,012 & 0,012 & 0,013 \\
\hline 3. subterraneus & 0,106 & 0,080 & $\begin{array}{c}0.022 \\
(0.003)\end{array}$ & 0,014 & 0,015 & 0,014 & 0,013 & 0,014 & 0,014 & 0,013 & 0,013 & 0,013 & 0,013 & 0,013 & 0,010 & 0,012 & 0,011 & 0,013 \\
\hline$\oiiint^{4 . s . s a v i i}$ & 0,113 & 0,118 & 0,115 & $\begin{array}{c}0.011 \\
(0.002)\end{array}$ & 0,007 & 0,012 & 0,013 & 0,012 & 0,011 & 0,012 & 0,013 & 0,013 & 0,014 & 0,015 & 0,013 & 0,010 & 0,012 & 0,015 \\
\hline $\begin{array}{l}\text { 5. } 5 \text { brachycercus }+ \\
: \approx \text { s. niethamericus }\end{array}$ & 0,125 & 0,126 & 0,120 & 0,046 & $\begin{array}{c}0.011 \\
(0.002)\end{array}$ & 0,011 & 0,013 & 0,013 & 0,013 & 0,013 & 0,013 & 0,013 & 0,015 & 0,015 & 0,014 & 0,012 & 0,013 & 0,016 \\
\hline 6. nebrodensis & 0,121 & 0,124 & 0,112 & 0,071 & 0,077 & $\begin{array}{c}0.005 \\
(0.002)\end{array}$ & 0,015 & 0,014 & 0,013 & 0,014 & 0,012 & 0,013 & 0,014 & 0,014 & 0,013 & 0,013 & 0,014 & 0,015 \\
\hline 7. gerbei & 0,082 & 0,093 & 0,094 & 0,090 & 0,095 & 0,106 & $\begin{array}{c}\mathbf{0 . 0 1 3} \\
(\mathbf{0 . 0 0 3})\end{array}$ & 0,011 & 0,012 & 0,011 & 0,012 & 0,012 & 0,012 & 0,012 & 0,011 & 0,008 & 0,009 & 0,012 \\
\hline 8. duodecimcostatus & 0,088 & 0,113 & 0,112 & 0,095 & 0,101 & 0,109 & 0,080 & $\begin{array}{c}0.025 \\
(0.005)\end{array}$ & 0,007 & 0,012 & 0,012 & 0,013 & 0,014 & 0,014 & 0,011 & 0,012 & 0,012 & 0,014 \\
\hline 9. lusitanicus & 0,084 & 0,112 & 0,105 & 0,087 & 0,102 & 0,102 & 0,079 & 0,049 & $\begin{array}{c}0.009 \\
(0.002)\end{array}$ & 0,012 & 0,012 & 0,012 & 0,013 & 0,014 & 0,011 & 0,011 & 0,012 & 0,014 \\
\hline 10. felteni & 0,095 & 0,094 & 0,094 & 0,096 & 0,097 & 0,109 & 0,071 & 0,084 & 0,079 & $\begin{array}{c}0.010 \\
(0.004)\end{array}$ & 0,012 & 0,011 & 0,011 & 0,012 & 0,011 & 0,010 & 0,009 & 0,013 \\
\hline 11. tatricus & 0,097 & 0,104 & 0,104 & 0,099 & 0,106 & 0,101 & 0,075 & 0,097 & 0,092 & 0,079 & $\begin{array}{c}\mathbf{0 . 0 0 5} \\
(\mathbf{0 . 0 0 2})\end{array}$ & 0,013 & 0,013 & 0,014 & 0,011 & 0,010 & 0,011 & 0,013 \\
\hline$\widehat{s} \quad$ 12. thomasi & 0,106 & 0,105 & 0,099 & 0,090 & 0,094 & 0,094 & 0,076 & 0,101 & 0,089 & 0,077 & 0,090 & $\begin{array}{c}\mathbf{0 . 0 0 8} \\
(\mathbf{0 . 0 0 2})\end{array}$ & 0,007 & 0,007 & 0,012 & 0,011 & 0,011 & 0,012 \\
\hline $\begin{array}{l}\cong \\
\stackrel{\Xi}{\Xi} 13 \cdot \text { atticus } \\
\cong\end{array}$ & 0,100 & 0,098 & 0,096 & 0,090 & 0,093 & 0,094 & 0,073 & 0,091 & 0,090 & 0,071 & 0,080 & 0,030 & $\begin{array}{c}\text { 0.001 } \\
(0.001)\end{array}$ & 0,003 & 0,012 & 0,013 & 0,013 & 0,014 \\
\hline 14. evia & 0,099 & 0,095 & 0,094 & 0,097 & 0,100 & 0,102 & 0,071 & 0,094 & 0,094 & 0,074 & 0,088 & 0,034 & 0,008 & $\begin{array}{c}0.005 \\
(0.002)\end{array}$ & 0,012 & 0,013 & 0,013 & 0,013 \\
\hline 15. multiplex & 0,085 & 0,090 & 0,086 & 0,091 & 0,099 & 0,102 & 0,071 & 0,079 & 0,074 & 0,071 & 0,075 & 0,078 & 0,078 & 0,080 & $\begin{array}{c}0.009 \\
(0.002)\end{array}$ & 0,009 & 0,010 & 0,013 \\
\hline 16. liechtensteini & 0,081 & 0,097 & 0,087 & 0,082 & 0,093 & 0,094 & 0,057 & 0,073 & 0,072 & 0,072 & 0,076 & 0,073 & 0,078 & 0,079 & 0,056 & $\begin{array}{c}0.009 \\
(0.003)\end{array}$ & 0,004 & 0,013 \\
\hline 17. bavaricus & 0,086 & 0,089 & 0,080 & 0,088 & 0,096 & 0,099 & 0,059 & 0,077 & 0,075 & 0,065 & 0,079 & 0,072 & 0,082 & 0,083 & 0,057 & 0,021 & $\begin{array}{c}0.008 \\
(0.002)\end{array}$ & 0,013 \\
\hline 18. outgroup & 0,101 & 0,115 & 0,116 & 0,138 & 0,147 & 0,146 & 0,102 & 0,119 & 0,115 & 0,112 & 0,107 & 0,109 & 0,112 & 0,113 & 0,097 & 0,108 & 0,101 & $\begin{array}{c}0.047 \\
(0.006)\end{array}$ \\
\hline
\end{tabular}

\footnotetext{
${ }^{a}$ Genetic distance within species (standard error)

${ }^{\mathrm{b}}$ Genetic distance between lineages (below the diagonal)
}

${ }^{\mathrm{c}}$ Standard error (above the diagonal) 